\title{
THE SHORT STORIES OF R. K. NARAYAN AND BASAVARAJ \\ NAIKAR: A COMPARATIVE STUDY
}

\section{Indalkar A.B.}

\author{
Ramkrishna Paramhansa Mahavidyalaya, Osmanabad (M.S.) India
}

Gmail: indalkar.supriya7@gmail.com

\begin{abstract}
The paper aims to compare and contrast themes in the short stories of R.K.Narayan and Basavaraj Naikar. Both short story writers are South Indian and published short stories of substantial merit. Their short stories are compared in terms of theme, locales and techniques. The striking contrast between the two authors is that R.K.Narayan belongs to the first generation of Indian English writers while Dr. Basavaraj Naikar is the representative of the present generation. R.K.Narayan cares neither to instruct nor to meditate but only to amuse his readers whereas Basavaraj Naikar has projected a very commendable critical skill as a story writer in presenting the salient thoughts of human mind. Naikar understands clearly ethical values of human life and criticizes its short comings through his characters. Both writers have written short stories dealing with friendship, education, corruption, cynicism, indifference at the administrative level, politics, marriage superstition, sex, greed for gold, the poverty, social evil, etc. R.K.Narayan's stories are short while the stories of Basavaraj Naikar are longish.
\end{abstract}

Keywords: Satire, Fictional world, Values, Comparison, Theme

\section{Introduction:}

The paper entitled The Short Stories of $\mathbf{R}$. K. Narayan and Basavaraj Naikar: A Comparative Study aims to compare and contrast the treatment of theme in the short stories of R. K. Narayan and Basavaraj Naikar. Both writers are South Indian and have published short stories of substantial merit. Being a pure artist at the core of his heart R.K.Narayan interprets Indian life aesthetically and with unprejudiced objectivity. Narayan's Malgudian world gives a glimpse of India, rather South India and invites comparison with the locales, themes, techniques of Dr.Basavaraj Naikar who is also a South Indian writer and representative of the present generation.

R.K. Narayan is a story teller par excellence. The variety of his themes and the manner of their treatment make his short stories sustained works of creation. Narayan's simplicity, ironic vision, his sense of humour, the narrative technique, the endless capacity to entertain the readers and the universal appeal of his fiction make him one of the supreme short story writers. Some of Narayan's stories are ironical, some mildly fantastic, some comic, some tragic but most of them reflecting the cross-section of social life in India in his era.

Narayan's Malgudi is his greatest invention where we find real people, real places in one harmony of day-today existence and eccentricity. Malgudi is not just a fictional town, but one teeming with characters, each with their own idiosyncrasies and attitude, making the situation as familiar to the reader as if it were their own backyard. Malgudi cannot be located on the map of India but it is alive like a character. Narayan has immortalized the region christened by him as Malgudi in his short stories and novels. What happens in Malgudi happens everywhere in India.

Narayan recreates the fictional world of childhood superbly and his genial humour makes his stories utterly charming and readable. His world of children is full of their innocent pranks, gaiety and garrulousness; as a result they bring the morning freshness of a spring flower. The themes of social evils such as greed, poverty, unemployment, dowry system, class and caste system, black-marketing, starvation, etc. find a place in his stories. $\mathrm{He}$ has his own way of dealing with the problems of society and he is content with mild criticism. His aim of satire is not the degradation of man but to show men the ways in which he has degraded himself.

Belief in silly superstitions is in the Indian blood and Narayan makes the best use of this aspect of Indian life in his stories 
dealing with superstition. His ghost stories deserve admiration for their appropriate atmosphere. The author has humanized the ghosts so they listen to reason, argue and cause no harm.

In his humorous stories, he creates the joyous sense of life beautifully. Narayan is a superb craftsman and comedian and he presents smiles and tears together, smiling through the tears in things and glimpsing the rainbow magnificence of life.

Narayan's writing is a distinctive blend of Western technique and Eastern material and he has succeeded in a remarkable way in making an Indian sensibility at home in English art. He makes use of first person narration effectively. His Bharat Brand of English respects the rules of law and maintains the dignity of grammar but still have a swadeshi stamp about it unmistakably.

Narayan's devotion, sincerity, artistry, his humanitarian point of view, his delightful sense of comedy, artistic beauty, objectivity, art of characterization assure him a distinctive place among the notable storytellers of the world.

Endowed with a rich imagination Basavaraj Naikar is certainly a conscious artist whose original stamp of artistic ability is reflected in his short stories. To him literature is a serious and committed vocation. Naikar has presented the South Indian life and culture in particular, and situations quite Indian in general. The portrayal of Indian culture as manifested in one of its important regions is an avowed objective of the short stories of Basavaraj Naikar. His stories represent various aspects of human relationship in our life. They range from the elemental to the social to the mythical dimensions of life.

Naikar's stories may be classified into two categories.

* Historical stories and Contemporary stories

Naikar's artistic talent is revealed in his portrayal of historical characters. His historical characters like Rani Mallamma, Kanakadasa the golden servant seem to be living characters of flesh and blood. The character of Rebellions Rani of Belavadi is memorable because she may be considered as a rare person, perhaps first who organized the women and train them up in fighting. Her personality as a good administrator, an able organizer, a ferocious fighter, a kind mother and ideal wife should be appreciated.

Naikar's preoccupation with present and contemporaneity in various forms and colours is quite clearly seen in his two collections of short stories. As an outstanding professor of English and renowned scholar Dr. Basavaraj Naikar has been closely associated with the academic world. Universities and colleges are considered to be the seats of learning and the higher educational institutions should be run by the lofty and noble men with high ideals. However, Basavaraj Naikar is hurt much by the corruption, hypocrisy, dirty politics, narrow-mindedness, jealousy in some of the post-graduate departments and universities. The author narrates the predicament of the rotten academic ambiance in our educational institutions. He exposes much of the reality of the present higher education in India. Naikar has two stories that deal with thieving and the significant aspect of these stories is that the better change takes place in the lives of the thieves.

In most of stories the greed for gold and lust happens to be the main theme. In some stories the author highlights the family bonds and sanctity of marriage vows. Naikar's characters are typically Indian in their sense of values and concerns, and cannot be separated from the main stream of Indian life. He believes in the view that Indians must write in our native brand of English and should not ape the British masters. Our imaginary and style should be redolent of our cultural ethos. Undoubtedly, the stories capture the attention of the readers on account of their Indian sensibilities. The real secret of Naikar's artistic performance is the simplicity of language, sincerity of art, gentle touch of humor and satire.

The striking contrast between the two writers is that R. K Narayan belongs to the first generation of Indian English writers while Naikar is the representative of the present generation. Both depict the South 
Indian ethos in particular and situations quite Indian in general.

R. K. Narayan is an ironist and humorist and is not unaware of the tragedy of the human situations. It is observed that Narayan is not an intolerant critic of Indian ways and modes. On the whole, he is content to snap Malgudi life's ironies. He cares neither to instruct nor to meditate but only to amuse his audience. His total acceptance of life is noteworthy, whereas Naikar has projected a very commendable critical skill as a story writer in presenting the salient thoughts of human mind. His realization of life on a variety of subjects from the mundane to the metaphysical, from politics to religion, from sexology to astrology and so on reflects his scholarship. As a social critic Naikar understands clearly ethical values of human life and criticizes its short comings through his characters. Without fear or favour, Naikar has made an assessment and evaluation of his mission with a whip of conscience on the back of the society

Almost all the stories of R. K. Narayan are short while the stories of Naikar are longish.

R. K. Narayan and Basavaraj Naikar are not happy with the present educational setup of our nation and are sympathetic and compassionate to learners. R. K. Narayan deals with child education while Basavaraj Naikar presents corruption, cynicism, indifference at the administrative level, apathy and incompetence at the academic level, fickleness at the level of students. Naikar brings out the foppery, meanness and petty politics of highly educated intellectuals in his stories dealing with campus life.

Friendship is one of the important themes in the short stories of R. K. Narayan and Basavaraj Naikar. In Naikar's stories the unfaithful friends are punished, however, in the stories of Narayan dealing with friendship, we don't find such treacherous friends. Narayan's doctor friend saves the life of his intimate friend while Naikar's doctor friend poisons his patient and kills him for the sake of money.

Narayan seems to believe in the principle of 'Art for the sake of Art'. His forte is pure and genial humour. On the other hand Naikar's stories are told with muffled humour and subtle satire on a society that is conservative and liberal, traditional and modern.

The problem of marriage and morals is one of the primary themes of Narayan and Naikar, They lay more emphasis on the sanctity of marriage. They depict Hindu wives whose primary obligation is towards their home and husband.

Greed for gold is at the root of all evils. Both writers express their concern over the loss of values and morals. Also they advocate the need for money to fulfill one's basic needs, but bring out the danger of its unlimited craze. Modern psychology regards sex as one of the most important aspects of life, and hence it is sexrelationship and sex conflicts which predominate in the fictional world. After close reading of the stories of writers, we realize that R.K. Narayan differs from Naikar in dealing with sex. Man and woman living together in Malgudi without getting married are regarded as sinners. Hence it is sacrilegious to violate the sanctity of sex. Sexual passion is not a theme which Narayan develops very convincingly in his fictional world. Naikar discusses sex openly whereas Narayan is suggestive. We find graphic descriptions of copulation in Naikar's stories.

It is observed that both writers criticize astrologers and superstitious people and suggest that as long as people remain credulous, such deceivers will continue to cheat people.

The poor people are drawn on the same line in terms of their appearance and miserable life. Gluttony is a sin. It leads to corruption. Sin leads to sin. There is only an entry into the world of sin but no exit. Corruption is the tempestuous force that disturbs the serene sea of morality. Narayan indirectly deals with social evil whereas Naikar seems to be a committed writer who vehemently criticizes the corrupt politicians. It is observed that both writers do not vehemently attack the ways of the thieves. They refer to their deft dealings and move on with a gentle smile. Both writers 
have sympathetic attitude towards thieves and beggars.

Both Narayan and Naikar make use of first person, third person and flashback method and make their stories utterly charming and readable. Both follow the tradition of storytelling as it existed in ancient India. The locale chosen by both writers is recognizably Indian and local colour is demonstrably the life of Narayan and Naikar's stories. The characters of Narayan and Naikar are typically Indian in their sense of values and concerns. They possess a sense of wonder and enjoy the fringes of life. Most of Naikar's women are weak, lustful and deceitful; on the other hand Narayan's women are pious, dutiful and gentle and are not involved in the illicit relationship.

Like other major writers both Narayan and Naikar come under the influence of our ancient classic lore as well as western masters. In their stories, we find, fine blending of Western technique and Eastern material. Narayan has no philosophical or socialistic concern like that of Naikar. Narayan's vision of life is subtly ironic and his irony is only an irony of recognition and not an irony of correction, whereas Naikar seems to be a social critic and points out the weaknesses and shortcomings of the people directly and his main concern is to project ethical values on his fictional world. R.K. Narayan's complete dependence on a purely artistic approach to literature sets him apart from Basavaraj Naikar and other Indian writers in English.

In conclusion we can say that R.K. Narayan's fictional world is comic while Naikar's world is moral. Narayan is not a didactic writer but he has an extraordinary power of evoking a sense of propriety in life. Like Basavaraj Naikar, R.K. Narayan is not a critic of society, but he is certainly a critic of conduct.

\section{References:}

Biswal, S.K. R.K. Narayan: A Critical Study. New Delhi: Omega Publications, 2011.

Das, Bijay Kumar. Postmodern Indian English Literature. New Delhi: Atlantic Publishers and Distributors, 2006
Dwevedi, A.N. Introduction to Contemporary Indian Short Story: An Overview. New Delhi: B.R. Publishers, 1991.

---. Papers on Indian Writing in English Vol. II: Fiction. New Delhi: Atlantic Publishers and Distributors, 2002.

Iyengar, K.R.S. Indian Writing in English. New Delhi: Sterling Publishers, 1962.

Melwani, Murli Das. Themes in the Indian Short Story in English: A Historical and Critical Survey. Bareilly: Prakash Book Depot, 2009.

Naikar, Basavaraj, ed. Indian English Literature Vol. I. New Delhi: Atlantic Publishers and Distributors, 2002.

Panigrahi, Prashant Kumar, ed. R.K. Narayan, The Guide. Delhi: Manglam Publications, 2010.

Prasad, Amar Nath, ed. Critical Response to R.K. Narayan. New Delhi: Sarup and Sons, 2003.

Ramnan Mohan G. Contemporary Indian Writers in English R. K. Narayan, An Introduction. New Delhi: Cambridge University Press, India 2013.

Singha, S.P. ed. Perspectives on Basavaraj Naikar. Ahmedabad (Gujrat): Shanti Prakashan. 2006.

Vennugopal, C.v. The Indian Short Story in English: A Survey. Bareilly: Prakash Book Depot. 1976. 